professional standards have been elevated. Some of the faults mentioned in my paper, especially of the more elderly men, are relics of this darker professional era. Time will solve this phase of the problem.

But there are other points in which defect would seem to be apparent. These defects are those recognized by every physician who attends medical society meetings. He recognizes that there is a certain proportion of their membership that does not come up to desirable professional standards. The war, by stripping away individual environment and placing all on the general level, has more clearly revealed these professional inequalities. The examining boards in the training camps brought them into strong relief.

Colonel Vaughan asks for information as to how these inequalities may be remedied. $\mathrm{He}$ and the other eminent medical men who have made such matters their life study are far better qualified than I am to work out the answer sought. But if there are divergences; and some tend to dip below the proper standards of professional competence, recognition of this fact necessarily implies the duty of attempting betterment by all interested.

Accordingly there are certain matters of such general nature that even $\mathrm{I}$ might venture an opinion on them. All are touched on in the original paper, and the following is merely a summary. It is therefore suggested:

(a) That all candidates for matriculation for the degree of Doctor of Medicine be given psychologic tests to determine their possession of mental qualities suitable for effectively taking up such an exacting science. These tests are now being employed in the hiring of artisans, clerks, etc., with a view to determining probable efficiency in their less scientific vocations.

(b) That medical schools whose curriculums still appear substandard or imperfect institute proper remedy.

(c) That such measures be taken as may be possible to insure that practitioners shall not unduly retrograde professionally after graduation. Some infuences operating to interfere with keeping up with professional progress are personal problems, relating to initiative, finance, environment or other matters. Others may be favorably affected through medical societies, meetings, etc. The encouragement of the profession, and especially of the less well equipped type, to take postgraduate courses of study at periodic intervals would be very valuable.

(d) That more exact standards of qualification in certain important specialties be required, and that those be recog. nized by special degrees or certificates, as is now the case, for example, with the Doctor of Public Health degree.

These suggestions do not imply anything impracticable. No one knows the mental attainments of the medical profession better than Colonel Vaughan, and I am sure that the matter of the acceptance of such suggestions, in whole or in part, may be safely left to him and his distinguished colleagues in medical education in this country.

Edward L. Munson, M.D., Washington, D. C

Brig.-Gen., M. C., U. S. Army.

\section{PROTEST INCREASE IN TAX UNDER NARCOTIC LAW}

To the Editor:-It seems that another outrage is about to be perpetrated on the medical profession of this country. I am in receipt of a demand from the collector of internal revenue for this district for the payment of $\$ 1.50$ for a narcotic license for the period from Jan. 1 to June $1,1919$. I have already paid for and secured a license covering the same period, and would like to know what power and authority they have to demand the payment of an additional tax. I have written the Internal Revenue Office propounding the following queries:

1. Is this license canceled by the act of Congress assessing the additional tax?

2. If so canceled should I not receive credit for the amount of tax already paid?

3. If not canceled, why the demand for the purchase of an additional license?
Something should be done to protect the interests of those who responded to the call to assist the nation in her hour of need and who are now compelled to start anew in the practice of their profession.

$$
\text { O. F. Miller, M.D., Byesville, Ohio. }
$$

To the Editor:-The recent increase in the tax required of physicians under the Harrison act is simply another example of what the profession has submitted to in the last few years. It is presumed that when a man is given a license to practice medicine he is competent to do so. The Harrison act practically denies that inference and imposes on the profession a tax before we can use certain drugs. Foolishly and tamely we submitted to this injustice, and now we are having further evidence in the increase of amount required to allow us to practice and use our judgment as to what drugs we shall employ. . . . The Harrison act may be the correct solution of the narcotic problem. I have positive doubts on that question; and if the profession is now going to sit quietly and allow the latest imposition to pass without protest, you can rest assured that something else will come up before long.

We allowed ourselves to be imposed on to the extent of paying for the carrying out of the Harrison act. The American Medical Association, while no: a political organization, should at its next meeting send a message to Congress that will not leave a doubt in the minds of that eminent body as to our feelings on the matter.

F. H. JAckson, M.D., Houlton, Maine.

To the Editor:-Under the Harrison act we paid the required $\$ 1$ license. Nine months later we are informed that Congress has increased the tax to $\$ 3$ per annum and that we remit to the collector of internal revenues $\$ 1.50$ for the first half of 1919. What puzzles me, and I suppose a number of other men, is what became of our tax money previously paid, and why were we not credited with the difference? It is not the amount but the principle of the thing we do not like. I suppose it is like the army game. You do what you are told and ask no questions.

ERWIN C. CARY, M.D., Reedsville, Wis.

To the Editor:-I am writing to get information that you may have in regard to the new law affecting the Harrison Narcotic Law. We have all no doubt paid our $\$ 1$ which gives us a license up to July 1,1919 . Now are we to pay an extra $\$ 1.50$ from Jan. 1,1919 , to July 1, 1919, or the balance due between the old and new fee?

K. E. B.

To the Editor:-Probably every practicing physician in the United States received notice to remit $\$ 1.50$ to the internal revenue collector of his district to pay for a special tax stamp in accordance with the law passed in 1918 and effective Jan. 1, 1919. Every practicing physician at this time has conspicuously posted in his office a special tax stamp which attests that he has paid his fee until June 30 , 1919, regardless of what new law may have been passed. Admitting that the raise in rate during the life of the 1918-1919 tax stamp is legal and nullifies the internal revenue collector's receipt, it is still odd that we are not credited with the 50 cents that undoubtedly was paid in 1918 and applies to the 1919 period from January 1 to June 30 . The collector, however, overlooks this credit and asks for the entire $\$ 1.50$.

In order to pay this little tax it is necessary for a great many physicians, in smail towns, to secure a money order for the amount, the fee for this being 3 cents, and also to supply a stamp, another 3 cents, making 6 per cent. on the dollar paid to the government for the sending of the tax to the government.

Why not take steps toward inducing the collectors to at least furnish franked envelops to those paying the revenue tax? I respectfully suggest to physicians that each person sending a remittance for the revenue tax drop the letter containing the remittance into the postoffice without a stamp thereon. The collector will be duly notified, and he will be required to expend 3 cents to send a 3 cent stamp to obtain the remittance. A concerted action by physicians would make the revenue department take notice, and try to save the 6 cents.

B. B. $\mathrm{S}$ 
[CommeNT.-The original Harrison law, approved Dec. 17, 1914, provided that "every person, partnership, association, company or corporation importing, manufacturing, producing, compounding, selling, dealing in, dispensing or giving away opium or coca leaves or any of their compounds or derivatives" must register on or before the first day of July annually and pay a special tax of $\$ 1$ per annum. Under this provision, physicians as well as others were required to register and pay the tax. The registration and the tax paid in June, 1918, covered the period to July 1, 1919. The Revenue Act of 1918 , approved Feb. 24, 1919, provides in addition to requiring annual registration on or before the first of July of each year that "every person who on Jan. 1, 1919, is engaged in any of the activities above enumerated (this enumeration being the same as in the original act) shall within thirty days after the passage of the act make like registration and pay the proportionate part of the tax for the period ending June 30, 1919." The act then provides for the following special tax in place of the old general tax of $\$ 1$ : "Importers, manufacturers, producers and compounders, $\$ 24$ per annum; wholesale dealers; $\$ 12$ per annum; retail dealers, $\$ 6$ per annum; physicians, dentists, veterinary surgeons, and other practictioners lawfully entitled to distribute, dispense, give away, or administer any of the aforesaid drugs to patients upon whom they in the course of their professional practice are in attendance, shall pay $\$ 3$ per annum." There is no provision for deduction or credit for the remaining portion of the tax paid under the old law. This would amount to 50 cents for the period from Jan. 1, 1919, to July 1, 1919. Internal revenue collectors for the various districts are now sending out notices and blanks to physicians directing them to return the registration blank with the proportionate tax of $\$ 1.50$ before April 25, 1919. District internal revenue collectors are acting under instructions from the commissioner of internal revenue at Washington, and have no option regarding the amount collected or the time when it is due. Congress is responsible for the law, and the commissioner of internal revenue and the secretary of the treasury are responsible for its interpretation and administration. In regard to the suggestion of B. B. S., the district collectors would have no authority to furnish franked envelops and could not do so without instructions from the Treasury Department at Washington.-ED.]

\section{GREETINGS FROM ROUMANIA}

To the Editor:-More than 250 English, French: and Roumanian physicians, at a fraternal banquet on the occasion of the Allied victory and the delivery of Roumania by the Allied army, send to the American Society of Medicine their warm and enthusiastic homage of admiration and profound esteem. The United States of America may be proud of the medical men who have accomplished wonders of devotion and self-abnegation. On this day of triumph our thoughts go with infinite thankfulness to the United States of America, glorious and victorious protector of the right and liberty of the people.

Long Live the United States of America, forever glorious and favoring the emancipation of nations.

Asociatiunea Generala a Medicilor din Romania,

Dr. Mirinesco, President,

Dr. Jean Jiano, Secretary.

\section{MEDICAL COLLEGE FUND NOT REDUCED}

To the Editor:-A news item published in The Journal recently indicated that the appropriations for the College of Medicine of the University of Nebraska had suffered considerably at the hands of the legislature. I am pleased to report that the reductions proposed by the house committee were not permitted to stand, and a slight change in the wording of the bill gives the College of Medicine the entire amount requested by the board of regents. A total of $\$ 380,000$ for the ensuing biennium is provided by the bill for the College of Medicine and University Hospital of the University of Nebraska at Omaha.

Irving S. CUtTkR, M.D., Omaha.

Dean, University of Nebraska College of Medicine.

\section{Queries and Minor Notes}

ANONYMOUS Communicatrons and queries on postal cards will not be noticed. Every letter must contain the writer's name and address, but these will be omitted, on request.

SPALTEHOLZ METHOD OF CLEARING SPECIMENS

To the Editor:-Please inform me where I may obtain detailed infor mation concerning the Spalteholz method of clearing tissues.

A. Poska, M.D., Seattle.

Answer.-We quote the following from an article by Sabin in Contributions to Embryology, 3, No. 7, Carnegie Institution of Washington, 1915, which contains the chief features of Spalteholz' method, with modifications by Sabin and others:

In general the essentials of the method are, first, fixation in formal dehyd; second, a thorough bleaching. of the tissues with hydrogen peroxid to remove the hemoglobin and other pigments; third, dehydration; and, fourth, clearing the specimens in an oil which has the same index of refraction as the tissues. As applied to embryonic tissues, the method, developed by Professor Spalteholz, is follows: The specimens, which have been injected with India ink, are fixed for from twenty-four to forty-eight hours in 5 and 10 per cent. liquor formaldehydi. Commercial formaldehyd solution is slightly acid, which is an advantage for the India ink injections, since the ink diffuses in an alkaline solution. Specimens which have been injected with silver nitrate are ruined by fixation in formaldehyd, because the silver salt is changed to a white precipitate which obscures the vessels. If injections of bone are desired the formaldehyd solution may be made slightly alkaline and the diffusion of the ink prevented as much as possible by tying off all vessels before fixation. For large fetuses, which are to be cleared in toto, Dr. P. G. Shipley has found that the subsequent bleaching is made easier by washing the specimen in running water before fixation, thus removing much of the hemoglobin. After fixation, the specimens are washed in running tap water from twelve to twenty-four hours, fol. lowed by distilled water to remove the formaldehyd. The bleaching is done in hydrogen peroxid. Spalteholz adds a few drops of ammonia to precipitate the barium salts. This is not necessary with bariumfree oxid. For adult tissues, Spalteholz uses undiluted peroxid; for the embryonic tissues about 2 to 3 per cent. is the best strength. The small embryos with ink injections take about twenty minutes to bleach; for the silver specimens, from two to three minutes suffice, and they must be watched constantly and the bleaching stopped before the silver is affected. Following the bleaching, the specimens must be washed thoroughly in running water and in distilled water. The dehydration may be begun with 50 per cent. alcohol and the percentage increased successively by five points or less. After two changes of a good grade of absolute alcohol, the specimens are passed through changes of benzene into the synthetic oil of wintergreen. The small amount of benzene which is carried over evaporates quickly, and the few bubbles which develop in the bleaching process can be removed with needles. The specimens may be made permanent in balsam.

Spalteholz' method is described by him in his book, "Ueber das Durchsichtigmachen von menschlichen und tierschen Präparaten, Ed. 2, Leipzig, S. Hirzel, 1914.

For this and additional methods of clearing tissues, reference may be made also to Guyer, M. F.: Animal Micrology, University of Chicago Press. 1917, p. 102.

NUMBER OF DEATHS AMONG PHYSICIANS IN THE UNITED STATES AND CANADA FROM 1915 TO 1919

To the Editor:-Please inform me how many physicians died and how many medical students graduated in the years 1915, 1916, 1917 and 1918 . Henry S. Murray, JR., M.D., New York City.

ANSWER.-The approximate number of deaths among physicians of the United States and Canada during the four years were: $1915,2,818 ; 1916,2,524 ; 1917,2,645$, and $1918,3,008$. During the same four years the number of medical students. gratuating were: $3,854,3,724,3,694$ and 3,077 .

REJECTIONS IN THE DRAFT AND THEIR CAUSES

To the Editor:-1. Has the United States government published any statistics relating to the proportion of rejections in the late draft to those who passed successfully?

2. Has it published anything relating to the cause of these rejections? Charees J. Foote, M.D., New Haven, Conn.

ANSWER-1. According to the first and second reports of the Provost Marshal-General, the total number of registrants under the first draft was $9,586,508$, of which $2,510,706$ were given physical examinations, $1,779,950$, or 70.89 per cent., were accepted, and 730,756 , or 29.11 per cent., were rejected. In 